JURNAL PLANS

Penelitian Ilmu Manajemen \& Bisnis

ISSN: 1978-7057

\title{
ANALISIS TEKNIKAL DENGAN METODE AUTOREGRESSIVE INTEGRATED MOVING AVERAGE (ARIMA) DAN GENERALIZED AUTOREGRESSIVE CONDITIONAL HETEROSCEDASTIC (GARCH) DALAM MEMPREDIKSI HARGA SAHAM PERUSAHAAN (Studi Pada Intiland Development Tbk)
}

\author{
Miftahul Jannah Pohan \\ Alumni Jurusan Manajemen Fakultas Ekonomi Universitas Negeri Medan \\ Cut Ermiati \\ Dosen Jurusan Manajemen Fakultas Ekonomi Universitas Negeri Medan
}

\begin{abstract}
Abstrak
Penelitian ini bertujuan untuk mengetahui keakuratan kedua metode peramalan yaitu ARIMA dan GARCH serta untuk mengetahui metode manakah yang lebih akurat. Data yang digunakan adalah data harian saham DILD selama tahun 2014 yang berjumlah 242 hari perdagangan. ARIMA dan GARCH merupakan metode peramalan yang menggunakan data timeseries. Hasil penelitian menunjukkan bahwa data harga saham DILD selama setahun bersifat tidak stasioner, sehingga data perlu ditransformasikan dengan uji pembeda. Data yang sudah stasioner dapat digunakan dalam peramalan dengan metode ARIMA dan menghasilkan model terbaik yaitu ARIMA $(1,1,1)$ yang memiliki unsur hetereroskedastisitas sehingga dapat dilakukan peramalan dengan metode GARCH dan memperoleh model terbaik yaitu GARCH $(1,1)$ setelah melakukan uji coba dengan beberapa model lainnya. Peramalan dengan metode ARIMA $(1,1,1)$ memiliki tingkat kesalahan absolute rata-rata sebesar 3,63\% sedangkan peramalan dengan model GARCH memiliki tingkat kesalahan absolut rata-rata sebesar $(20,03) \%$. Dari hasil diatas, dapat disimpulkan bahwa metode ARIMA lebih akurat daripada metode GARCH dalam memprediksi harga saham perusahaan Intiland Development Tbk.
\end{abstract}

Kata Kunci : Analisis Teknikal, Harga Saham DILD, ARIMA, GARCH

\section{PENDAHULUAN}

Motivasi dalam melakukan sebuah investasi adalah untuk mendapatkan keuntungan dari transaksi investasi yang dilakukan. Para investor senantiasa menaruh harapan akan mendapatkan manfaat dari kegiatan investasi yang mereka lakukan. Semakin tinggi investasi yang ditanam, tentunya semakin tinggi pula hasil yang diharapkan. Oleh karena itu, investor akan sangat hati-hati dalam melakukan investasi. Salah satu bentuk kehatihatian tersebut adalah dalam mengantisipasi perubahan harga return saham, maka diperlukan analisis dan peramalan untuk memprediksi perkembangan harga dan return harga saham di masa yang akan datang.

Peramalan merupakan pembelajaran atas studi terhadap data historis untuk menentukan hubungan, kecendrungan dan pola secara sistematis. Peramalan selalu mengarah kepada kejadian-kejadian dimasa mendatang sehingga diperlukan peramalan tentang keadaan yang akan datang. 
Dalam kegiatan peramalan, seringkali terjadi ketidak-akuratan pada hasil peramalan karena pada dasarnya kita berada pada lingkungan yang memiliki unsur ketidakpastian, tetapi suatu keputusan tetaplah harus ditetapkan karena akan mempengaruhi masa depan suatu individu atas organisasi itu sendiri.

Peramalan harga saham dapat dianalisis melalui dua cara, yaitu dengan menggunakan analisis fundamental dan analisis teknikal. Analisis fundamental yaitu melakukan peramalan harga saham berdasarkan pada data-data, berita-berita, dan angka-angka sebagai dasar pengambilan keputusan pembelian saham dan biasanya dilakukan dalam kegiatan investasi jangka panjang. Analisis ini digunakan untuk melihat dan memprediksi seberapa besar dividen yang diterima oleh inverstor selama melakukan kegiatan investasi. Sedangkan analisis teknikal merupakan analisis yang berdasarkan pada grafik harga dan volume saham terdahulu sebagai dasar dalam peramalan jual atau beli saham. Analisis teknikal merupakan analisis yang digunakan dalam kegiatan investasi jangka pendek, dimana analisis ini digunakan untuk melihat dan memprediksi seberapa besar capital gain dari aktivitas perdagangan saham yang dilakukan.

Analisis fundamental mendasarkan pada faktor-faktor fundamental, yaitu kondisi lingkungan bisnis yang berpengaruh pada suatu industri tertentu dan kondisi internal perusahaan yang sahamnya akan dibeli seperti, laporan keuangan, informasi penting lain yang sewaktu-waktu harus diumumkan perusahaan publik (seperti, pengumuman pembagian dividen, stock split, right issue dan corporate action lainnya) perkembangan ekonomi makro serta berita dalam bidang-bidang lain seperti politik, sosial, keamanan negara dan informasi lainnya. Sedangkan analisis teknikal lebih mendasarkan pada fluktuasi harga dan kecendrungan (trend) harga saham yang bersangkutan di bursa efek. Perbedaan dari kedua analisis ini dalam memprediksi harga saham adalah analisis fundamental lebih menekankan pada pentingnya nilai wajar saham dengan data pendukung, sedangkan analisis teknikal hanya membutuhkan grafik harga dan volume penjualan di masa lalu.

Analisis teknikal banyak digunakan oleh kaum spekulan, yaitu para investor yang melakukan pembelian maupun penjualan sekuritas dalam jangka pendek untuk mencari keuntungan jangka pendek (Taswan \& Soliha, 2002). Memang keuntungan yang ingin diraih adalah abnormal return (return yang besar/ tidak normal), namun resikonya pun sangat besar.

Bodie, Kane dan Marcus (2006) menyatakan bahwa analisis teknikal (technical analysis) pada dasarnya merupakan upaya pencarian pola perulangan yang dapat diprediksi dalam harga saham. Meskipun para pengguna teknik ini mengakui nilai informasi yang terkait dengan prospek ekonomi perusahaan dimasa depan (dalam analisis fundamental), tetapi dalam analisis teknikal percaya bahwa, informasi tersebut belum tentu menjadi 
strategi perdagangan yang dapat diandalkan. Hal ini dikarenakan analisis fundamental dalam merespon harga saham cukup lambat.

Analisis teknikal adalah suatu jenis analisis yang berorientasi kepada harga (pembukuan, penutupan, tetinggi dan terendah) dari suatu instrumen investasi pada time frame (price oriented) sejalan dengan apa yang dikemukakan oleh Husnan (2009) bahwa "analisa ini merupakan upaya untuk memperkirakan harga saham (kondisi pasar) dengan mengamati perubahan harga saham tersebut (kondisi pasar) di waktu yang lalu".

Ada beberapa indikator analisis teknikal yang dapat digunakan sebagai metode peramalan, yaitu indikator volume dan analisis gelombang, indikator teori siklus, indikator filter, indikator momentum, analisis garis trend, Stochastic Oscillator (SO), Moving Average (MA), Exponential Moving Average (EMA), serta metode lainnya yang dapat digunakan untuk memprediksi harga saham, seperti Metode GARCH (Generalized Autoregressive Conditional Heteroscedasticity), VAR (Vector Autoregressive) serta Metode CAPM (Capital Asset Pricing Mod el).
Dibandingkan dengan beberapa metode prediksi lainnya, ARIMA dan GARCH paling sesuai dengan karakteristik data yang didapat dari pasar saham, yaitu data time series. Inilah alasan mengapa peneliti memilih metode ARIMA dan GARCH dalam melakukan analisis teknikal.

Sampai saat ini, terdapat 9 (sembilan) sektor perusahaan yang terdaftar di Bursa Efek Indonesia, diantaranya adalah sektor pertanian; sektor pertambangan; sektor industri dasar dan kimia; sektor aneka industri; sektor industri barang konsumsi; sektor properti dan real estate; sektor infrastruktur, utilitas dan transportasi; sektor keuangan; dan sektor perdagangan, jasa dan investasi. Dari kesembilan sektor diatas, sektor properti merupakan salah satu sektor yang memiliki pergerakan harga saham yang berfluktuatif.

Dari keseluruhan perusahaan properti, peneliti membandingkan 10 (sepuluh) perusahaan yang dianggap memiliki tingkat fluktuatif yang tinggi dibandingkan dengan perusahaan lainnya jika dilihat dari pergerakan harga saham selama lima tahun.

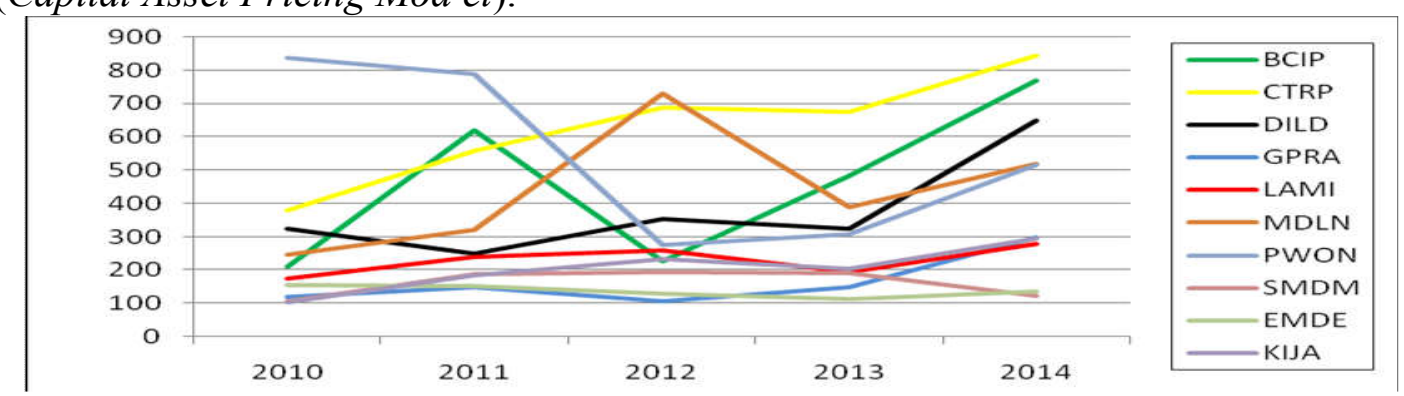

Sumber : www.idx.com (data diolah)

Gambar 1. Grafik Pergerakan Harga Saham Sepuluh Perusahaan Properti Selama 5 Tahun 
JURNAL PLANS

Penelitian Ilmu Manajemen \& Bisnis

ISSN: 1978-7057

Dari gambar di atas, dapat dilihat bahwa saham perusahaan DILD merupakan perusahaan yang pergerakan sahamnya memiliki tingkat fluktuatif yang tinggi setiap tahunnya dibandingkan dengan perusahaan lainnya. Berikut adalah gambar pergerakan volume perdagangan pada perusahaan Properti selama 5 tahun.

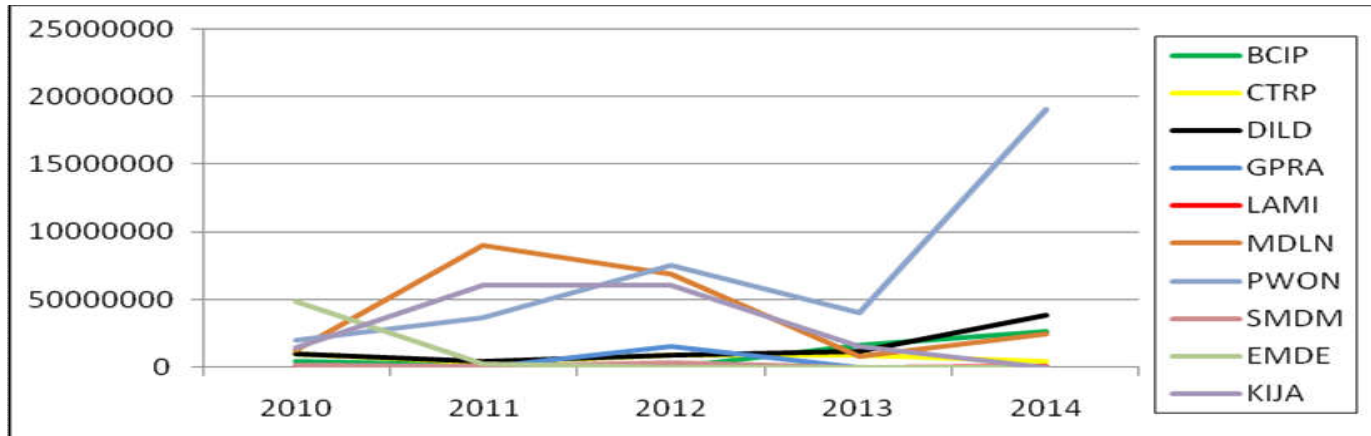

Sumber : www.idx.com (data diolah)

Gambar 2. Grafik Pergerakan Volume Perdagangan Saham Sepuluh Perusahaan Properti selama 5 Tahun

Dari gambar di atas, dapat dilihat bahwa pergerakan volume perdagangan dari kesepuluh perusahaan properti memiliki fluktuatif yang tinggi. Perusahaan DILD termasuk memiliki pergerakan volume yang relatif tinggi, meskipun besarnya volume tidak sebesar volume dari saham lainnya. Penelitian ini menggunakan data harian saham perusahan Intiland Development Tbk di BEI selama satu tahun yaitu mulai 2 Januari 2014 hingga 30 Desember 2014. Objek penelitian pengambilan data selama satu tahun sebanyak 242 hari perdagangan.

\section{METODE PENELITIAN}

Lokasi Penelitian

Informasi penelitian dilakukan di Sumatera Utara dengan mengakses data dari situs resmi Bursa Efek Indonesia (BEI) pada http://www.idx.co.id dan JSX Daily Statistics.

\section{Populasi dan Sampel Penelitian}

Populasi yang digunakan dalam penelitian ini adalah seluruh data harga saham perusahaan Intiland Development Tbk sejak terdaftar di Bursa Efek Indonesia pada tanggal 4 September 1991.

Sampel dalam penelitian ini adalah data harga saham perusahaan Intiland Development Tbk mulai periode 2 Januari 2014 sampai dengan 30 Desember 2014 (sebanyak 242 hari perdagangan). Penelitian sampel ini berdasarkan pada data terakhir yang dirilis saat penelitian ini akan dilakukan.

\section{Variabel Penelitian dan Defenisi Operasional Variabel Penelitian}


JURNAL PLANS

Penelitian Ilmu Manajemen \& Bisnis

ISSN: 1978-7057

Penelitian ini menggunakan variabel:

a. Perusahaan Intiland Development Tbk.

b. Metode ARIMA.

c. Metode GARCH.

\section{Defenisi Operasional}

Sesuai dengan variabel penelitian yang dijelaskan di atas, maka defenisi operasional dalam penelitian ini, yaitu :

1. Perusahaan Intiland Development Tbk

Intiland Development Tbk didirikan tanggal 10 Juni 1983 dan memulai kegiatan usaha komersialnya sejak 1 Oktober 1987. Kantor pusat DILD beralamat di Intiland Tower, Penthouse, Jl. Jenderal Sudirman Kav. 32, Jakarta.

DILD tergabung dalam kelompok usaha Intiland. Pemegang saham yang memiliki 5\% atau lebih saham DILD adalah Truss Investment Partners Pte. Ltd. (melalui kustidian UBS AG Singapore) dengan pengendali $22,24 \%$ dan Strand Investment Ltd. (melalui kustodian Credit Suisse Singapore) dengan kendali $19,89 \%$.

Berdasarkan Anggaran Dasar Perusahaan, ruang lingkup kegiatan DILD terutama meliputi bidang usaha pembangunan dan persewaan perkantoran. Saat ini, bisnis utama DILD meliputi kawasan perumahan, bangunan tinggi berkonsep, perhotelan, dan kawasan industri.

Pada tanggal 21 Oktober 1989, DILD memperoleh pernyataan efektif dari Menteri Keuangan Republik Indonesia untuk melakukan Penawaran Umum Perdana Saham DILD (IPO) di
Bursa Paralel kepada masyarakat. Dan dicatat pada tanggal 15 Januari 1990. Sedangkan pada tanggal 4 September 1991, Intiland Development Tbk tercatat di Bursa Efek Indonesia.

\section{Metode ARIMA}

ARIMA berfungsi untuk menyempurnakan model AR, MA dan ARMA. Model ini umumnya dirumuskan dengan:

$$
\begin{aligned}
& Y t=b_{0}+b_{1} Y_{t-1}+\ldots+b_{n} Y_{t-n}-a_{1} \\
& e_{t-1}-a_{n} e_{t-n}+e_{t}
\end{aligned}
$$

Model ini akan stasioner jika : $\mathbf{b}_{\mathbf{1}}+\mathbf{b}_{\mathbf{z}}<\mathbf{1}$. Model ARIMA biasanya dilambangkan dengan ARIMA (p,d,q) yang berarti bahwa model tersebut menggunakan $\mathrm{p}$ nilai lag dependen, $\mathrm{d}$ tingkat proses differensial dan q lag residual.

3. Metode GARCH

Pada model GARCH, varian residual $\left(\sigma_{\mathrm{t}}^{2}\right)$ tidak hanya dipengaruhi oleh residual periode lalu $\left(e_{t-1}^{2}\right)$ tatapi juga varian residual periode lalu $\left(\mathbf{\sigma}_{\tau-1}^{2}\right)$. Secara umum model GARCH yakni GARCH $(p, q)$ dinyatakan dalam bentuk persamaan dibawah ini:

$\sigma_{\mathrm{t}}^{2}=\alpha_{0}+\alpha_{1} e_{\mathrm{t}-1}^{2}+\ldots .+\alpha_{\mathrm{p}} \mathbf{e}_{\mathrm{t}-\mathrm{n}}^{2}$

$+\mathrm{B}_{1} \mathrm{O}_{\mathrm{z}-1}^{2 \mathrm{z}}+\ldots .+\mathrm{B}_{\mathrm{p}} \mathrm{O}_{\mathrm{z}-\mathrm{n} .}^{2}$

\section{Teknik Analisis Data}

Uji Stasioner

Seperti yang telah dikemukakan bahwa data yang dianalisis ARIMA dan GARCH merupakan data time series. Uji stasioner data dilakukan 
dengan uji koefisien otokorelasi, berupa tampilan korelogram ACF (Auto Correlation Function) yang berfungsi untuk mengidentifikasi sifat stasioner data yang menjelaskan suatu proses korelasi dan memberikan informasi mengenai hubungan antara data-data runtun waktu yang berdekatan. Koefisien otokorelasi menunjukkan keeratan hubungan antara nilai variabel yang sama untuk periode waktu yang berbeda yang disebut dengan time lag.

Selanjutnya akan dilakukan pengujian stasioner data secara kumulatif dengan uji ADF (Aumented Dickey-Fuller) yang berfungsi untuk menentukan apakah suatu data runtun waktu mengandung akar unit atau bersifat non-stasioner. Apabila data belum stasioner maka selanjutnya akan dilakukan uji pembedaan.

\section{Uji Differencing}

Uji Pembedaan digunakan untuk mengubah data yang tidak stasioner menjadi data stasioner melalui Transformasi Box-Cox. Data asli $\left(Y_{t}\right)$ digantikan dengan perbedaan pertama data sli tersebut. Model ini dirumuskan:

$$
\mathrm{d}(1)=Y_{t}-Y_{t-1}
$$

Jika setelah transformasi nilai rata-rata atau varians telah konstan, berarti data sudah stasioner. Dalam uji pembeda diperlukan uji kointegrasi. Muis (2008) menyatakan bahwa "Kointegrasi terjadi bila dua variabel atau lebih yang masing-masing variabel merupakan data tidak stasioner atau random walk, berkombinasi secara linier dan menghasilkan data runtun waktu yang stasioner.

Nilai uji kointegrasi berupa nilai kritis (Critical), probabilitas (Prob) dan Trace (t-statistik). Penelitian ini menggunakan nilai kritis dengan taraf signifikansi sebesar 5\% ( $\alpha=5 \%)$.

Data dari proses pembedaan tersebut digunakan kembali untuk membuat fungsi autokorelasi (correlogram) dan uji akar-akar unit (Dickey-Fuller) dengan program Eviews. Setelah data sudah stasioner, maka tahap selanjutnya adalah pembentukan model ARIMA dan GARCH untuk mendapatkan model terbaik dalam memprediksi Indeka Harga Saham Gabungan di BEI.

\section{HASIL PENELITIAN DAN PEMBAHASAN \\ Hasil Penelitian \\ Analisis Data}

stasioner, selanjutnya adalah menentukan nilai autoregressive (p), differencing (d), dan moving average (q), apakah melalui proses ARMA atau ARIMA. Jika terdapat unsur heteroskedastisitas maka selanjutnya adalah menentukan nilai ARCH (p) dan GARCH (q). Nilai $p, d$ dan $q$ pada ARIMA dan nilai $p, q$ pada GARCH digunakan untuk mengetahui model terbaik yang digunakan dalam peramalan. Tetapi sebelum menentukan model terbaik, terlebih dahulu dilakukan uji kestasioneran data, uji differencing serta pengujian koefisien autoregresi.

Berikut adalah data yang disajikan pada penelitian ini yaitu data harian harga saham penutupan DILD 
JURNAL PLANS

Penelitian Ilmu Manajemen \& Bisnis

ISSN: 1978-7057

periode 2 Januari 2014 sampai dengan 30 Desember 2014.

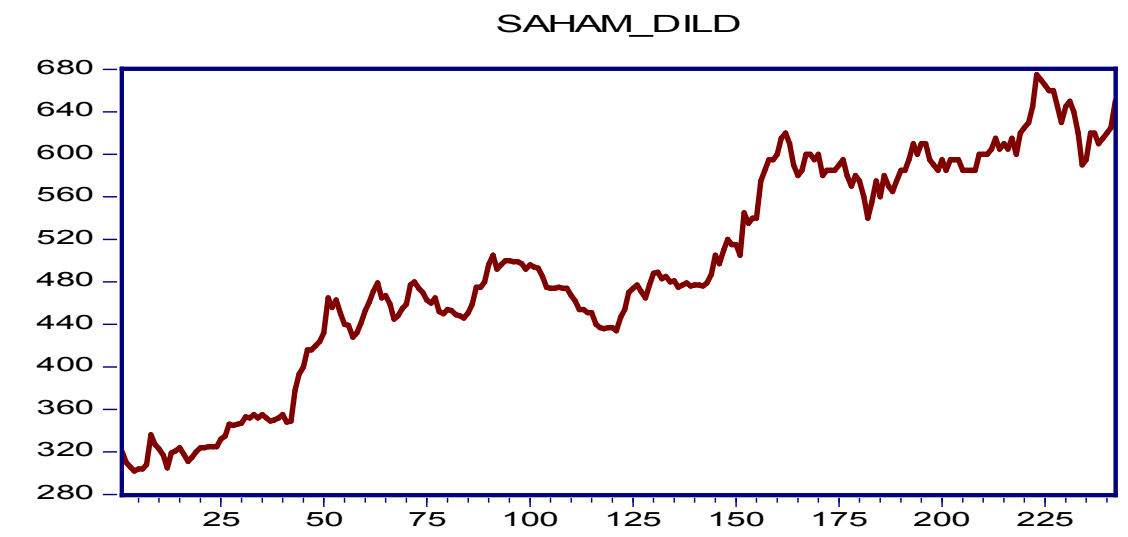

Sumber : JSX Daily (data diolah)

Gambar 3. Grafik Pergerakan Harga Saham DILD tahun periode 2014

Pada gambar diatas dapat dilihat bahwa data pergerakan harga saham DILD menunjukkkan adanya pola trend naik dan memiliki variansi yang cukup tinggi. Hal ini berarti bahwa data tidak stasioner sehingga perlu dilakukan uji pembeda agar data menjadi stasioner.

\section{Uji Kestasioneran Data}

Kestasioneran data diperiksa dengan analisis otokorelasi dan otokorelasi parsial (Aritonang, 2002). Seperti yang telah dikemukakan sebelumnya, bahwa data yang dianalisis dalam ARIMA dan GARCH adalah data yang bersifat stasioner. Data yang stasioner adalah data yang memiliki nilai rata-rata dan varians yang relatif konstan sepanjang periode pengamatan.

Uji otokorelasi untuk stasioner data time series menggunakan time lag (selisih waktu) selama 1 hari. Umumnya, batas interval lag secara otomatis sudah dihitung dalam program eviews sampai 36 lag. Tetapi dalam penelitian ini dibatasi sampai 21 lag.

Dari hasil yang diperoleh, dapat dilihat bahwa koefisien autokorelasi berbeda secara signifikan dari nol dan kemudian mengecil secara perlahan. Sedangkan koefisien autokorelasi parsial mendekati nol setelah lag pertama. Dari kedua koefisien ini dapat disimpulkan bahwa saham DILD tidak stasioner, sehingga pemodelan ARIMA dan GARCH tidak bisa digunakan, mengingat data yang digunakan dalam pemodelan haruslah bersifat stasioner.

Setelah melakukan uji otokorelasi dan otokorelasi parsial, selanjutnya adalah dengan melakukan uji ADF (Augmented Dickey-Fuller) yang merupakan uji yang menentukan apakah suatu data runtun waktu mengandung akar unit (unit root). Jika probabilitas $<5 \%$, maka tidak terjadi akar unit dan hal ini berarti bahwa data sudah stasioner. Dan sebaliknya jika probabilitas $>5 \%$, maka terjadi akar unit dan hal itu berarti bahwa data belum stasioner. Dari hasil uji unit, dapat diketahui bahwa nilai probabilitas adalah sebesar 0,7710 , dan 
JURNAL PLANS

Penelitian Ilmu Manajemen \& Bisnis

ISSN: 1978-7057

nilai probabilitas tersebut lebih tinggi dibandingkan dengan tingkat $\alpha=5 \%=$ $-2,873339$, hal ini berarti bahwa data harga saham DILD belum stasioner, maka perlu diadakan uji pembeda (differencing) dan derajat integrasi.

\section{Uji differencing}

Langkah selanjutnya adalah mentransformasikan data yang tidak stasioner dengan proses pembeda (differencing). $Y_{t}$ yang merupakan data asli diganti dengan pembeda pertama data asli tersebut. Dengan kata lain proses pembeda pertama ini dilakukan dengan cara mengurangkan data awal $\left(\mathrm{Y}_{\mathrm{t}}\right.$ dengan data nilai sebelumnya $\left(\mathrm{Y}_{\mathrm{t}}-\right.$ $\left.\mathrm{Y}_{\mathrm{t}-1}\right)$. Hasil uji pembedaan pertama dapat digambarkan dalam bentuk grafik dibawah ini:

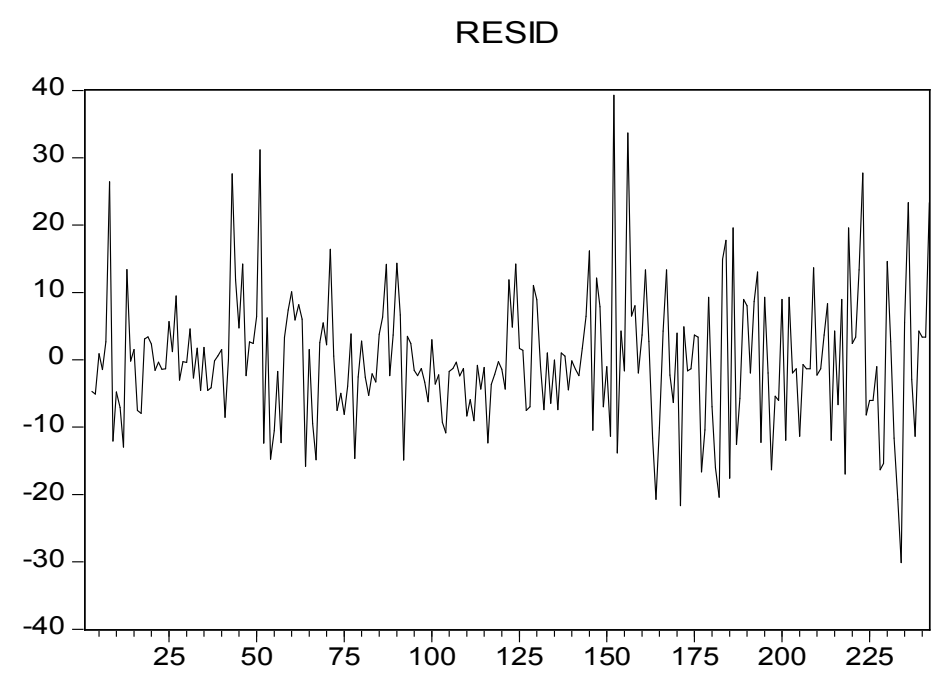

Sumber : Data diolah

Gambar 4. Data differencing Saham DILD

Dari gambar diatas, data saham DILD telah melalui proses differencing tingkat pertama. Dari gambar tersebut dapat disimpulkan bahwa data yang diamati sudah stasioner. Hal ini dapat dilihat dari gambar yang menunjukkan bahwa rata-rata dan variansi sudah mendekati nol, dan grafik tidak mencerminkan tren atau kecenderungan. Selanjutnya, membuat correlogram dengan menggunakan data yang telah digunakan pada proses pembeda pertama.
Dari hasil perhitungan fungsi otokorelasi dan otokorelasi parsial dari data yang telah mengalami proses differencing pertama, dapat dilihat bahwa terdapat satu koefisien yang signifikan yaitu pada lag 15, dimana dengan $\alpha=5 \%$ dan $\mathrm{n}=241$, maka batas intervalnya adalah $0 \pm 1,96 /(\sqrt{241})$ atau $0 \pm 0,126$. Dari tabel 4.5 dapat dilihat bahwa koefisien otokorelasi parsial pada lag 15 melebihi confidence limit yaitu rk lag $15=-0.130>-0,126$. 
Pembahasan Penelitian

Keakuratan metode ARIMA dalam memprediksi harga saham perusahaan Intiland Development Tbk.

Sebelum memprediksi harga saham perusahaan Intiland Developmment, langkah awal yang harus dilakukan adalah dengan melakukan uji kestasioneran data. Uji kestasioneran data yang digunakan pada penelitian ini adalah uji correlogram yang dibatasi sampai 21 lag. Pada uji ini, data belum bersifat stasioner, sehingga dilakukan uji stasioner data selanjutnya yaitu uji ADF dan uji PACF, dimana data yang dihasilkan adalah data variabel memiliki probabilitas sebesar $0,7710>$ $\alpha=5 \%=-2,873339$. Hasil ini menunjukkan bahwa terdapat akar unit dan data belum stasioner.

Langkah selanjutnya adalah dengan melakukan uji pembeda (differencing) pertama. Differencing pada tingkat pertama menghasilkan data yang memiliki rata-rata dan variansi yang mendekati nol. Hal ini berarti menunjukkan bahwa data sudah stasioner. Pada tahap ini, terdapat satu lag yang signifikan yaitu pada lag 15 yang nilainya melebihi batas confidence limit.

Uji pembedaan yang dilakukan satu kali otomatis menunjukkan bahwa ordo metode ARIMA pada $\mathrm{d}$ adalah 1 $(\mathrm{d}=1)$, sedangkan ordo AR dan MA juga bernilai 1. Jadi model ARIMA terbaik yang dipergunakan dalam peramalan ini adalah model ARIMA $(1,1,1)$.

Setelah model ARIMA terbaik ditetapkan, maka yang harus dilakukan selanjutnya adalah melakukan uji koefisiensi penduga yang menghasilkan nilai konstantaa (C) $=1,444857, b_{15}=0,257125$ sedangkan $\mathrm{a}_{15}=-0,203218$, sehingga diperoleh persamaan dengan model : $\mathbf{Y}_{\mathbf{t}}=\mathbf{b}_{\mathbf{0}}+$ $b_{15} Y_{t-15}-a_{15} e_{t-15}+e_{t}$. Setelah mendapatkan persamaan model terbaik, maka tahap selanjutnya adalah melakukan peramalan dengan metode ARIMA.

Peramalan dilakukan dengan cara membandingkan hasil peramalan dengan data aktual harga saham DILD pada bulan Januari 2015 dengan jumlah hari perdagangan sebanyak 15 hari. Hasil prediksi dengan tingkat kesalahan terbesar terjadi pada prediksi ke 7 sebesar 82 tingkat kesalahan terkecil terjadi pada prediksi ke 9 sebesar 4 . Sedangkan secara rata-rata, kesalahan simpangan absolut rata-rata sebesar 15,47, kesalahan kuadrat rata-rata sebesar 924,4, persentase kesalahan absolut rata-rata sebesar $3,63 \%$ sedangkan persentase kesalahan ratarata sebesar 2,35\%. Dari analisis data diatas, dapat disimpulakan bahwa keakuratan metode ARIMA dalam memprediksi harga saham perusahaan Intiland Development sebesar 3,63\% dengan model ARIMA $(1,1,1)$.

Keakuratan metode GARCH dalam memprediksi harga saham perusahaan Intiland Development Tbk

Sebelum melakukan pemodelan $\mathrm{GARCH}$, langkah yang dilakukan adalah dengan memeriksa unsur heteroskedastisitas atau identifikasi ARCH pada data yang sudah diestimasi ARIMA $(1,1,1) \quad$ sebelumnya. 
Pemeriksaan unsur heteroskedastisitas dilakukan dengan dua cara yaitu pola residual kuadrat pada correlogram dan uji ARCH-LM. Hasil pengujian terhadap residual kuadrat adalah nilai statistik LB (ditunjukkan oleh nilai obs $^{*}$ r-square) sebesar 1,816 adalah lebih besar dari nilai kritis statistika dari tabel distribusi chi squares yaitu sebesar 0,1777. Hasil pengujian ini menunjukkan bahwa terdapat unsur $\mathrm{ARCH}$ atau heteroskedastis.

Langkah selanjutnya adalah dengan mencoba-coba model GARCH, yang terdiri dari ARCH (1), ARCH (2), GARCH $(1,1)$, GARCH $(1,2)$, GARCH $(2,1)$ dan GARCH $(2,2)$. Dari keenam uji coba model tersebut, model GARCH (1,1) merupakan model terbaik karena memiliki nilai $R$-squares paling besar dibandingkan kelima model lainnya yaitu sebesar 0,002432 . GARCH $(1,1)$ memiliki koefisien konstanta sebesar 9,637978, $\alpha_{1}$ sebesar 0,180319 sedangkan $\beta_{1}$ sebesar 0,801901. Selanjutnya dilakukan evaluasi model yang menghasilkan nilai AIC sebesar 7.432053 yang nilainya lebih rendah dari AIC ARIMA sebesar 7,462766. Hal ini menunjukkan bahwa model GARCH $(1,1)$ merupakan model peramalan GARCH terbaik.

Setelah itu, dilakukan pengujian pola residual kuadrat correlorgam dan uji ARCH-LM kembali, untuk memastikan sudah tidak ada lagi unsure heteroskedastisitas. Hasil dari uji ini adalah nilai statistik LB sebesar 0,016237 dimana nilai ini lebih rendah dari nilai kritis chi-squares yaitu sebesar 0,8986. Hal ini menunjukkan bahwa sudah tidak adanya unsur heteroskedastisitas. Dan membuktikan bahwa model GARCH $(1,1)$ merupakan model terbaik dalam melakukan peramalan terhadap pergerakan harga saham perusahaan DILD. Sehingga persamaan model GARCH $(1,1)$ adalah : $\sigma_{\mathrm{t}}^{2}=\alpha_{0}+\alpha_{1}$ $\mathrm{e}_{\mathrm{t}-1}^{2}+\beta_{1} \mathrm{e}_{\mathrm{t}-1}^{2}$. atau $\sigma_{\mathrm{t}}^{2}=9,637978+$ $0,108319 \mathrm{e}_{\mathrm{t}-1}^{2}+0,801901 \sigma_{\mathrm{t}-1}^{2}$. Setelah mendapatkan model persamaan terbaik, maka tahap selanjutnya adalah melakukan peramalan. Sama halnya dengan ARIMA, peramalan dilakukan dengan cara membandingkan hasil peramalan dengan data aktual harga saham DILD pada bulan Januari 2015 dengan jumlah hari perdagangan sebanyak 15 hari. Sedangkan secara rata-rata, kesalahan kuadrat rata-rata sebesar 128,33, sedangkan persentase kesalahan absolut rata-rata sebesar 20,03\%. Dari analisis data diatas, dapat disimpulkan bahwa keakuratan metode GARCH dalam memprediksi harga saham perusahaan Intiland Development sebesar 20,03\% dengan model GARCH $(1,1)$.

Perbandingan keakuratan antara metode ARIMA dan GARCH dalam memprediksi harga saham perusahaan Intiland Development Tbk 


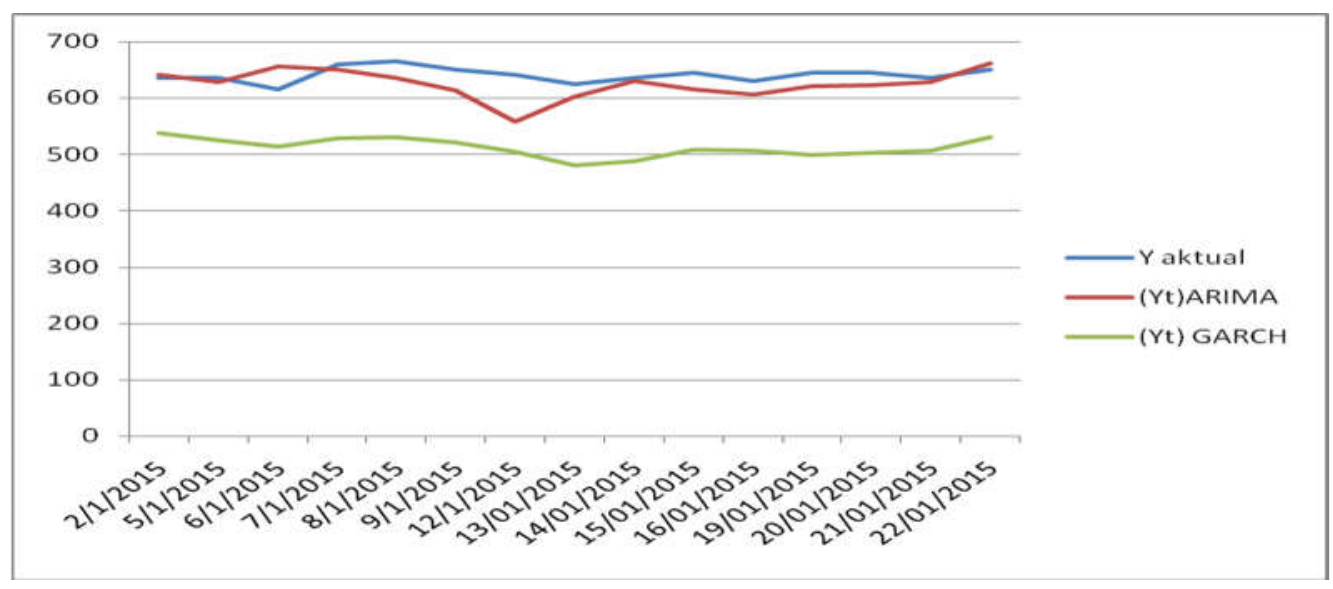

Sumber : data diolah

\section{Gambar 5. Grafik Perbandingan Keakuratan Metode ARIMA Dan GARCH Dalam Memprediksi Saham DILD Dengan Harga Saham DILD Aktual.}

Gambar di atas merupakan grafik perbandingan keakuratan peramalan dengan menggunakan metode ARIMA dan GARCH dengan harga saham DILD akutual. Dari hasil peramalan dengan metode ARIMA dan GARCH, dapat disimpulkan bahwa metode ARIMA $(1,1,1)$ dengan tingkat kesalahan absolut ratarata sebesar 3,63\% lebih akurat dari pada hasil peramalan dengan menggunakan metode GARCH $(1,1)$ dengan tingkat kesalahan absolut ratarata sebesar 20,03\% dalam memprediksi harga saham perusahaan Intiland Development pada periode Januari 2015 yang berjumlah 15 hari perdagangan.

Hasil dari penelitian ini juga membuktikan teori Elliot Wave yang dikemukakan oleh Ralp Nelson Elliot yang menyatakan bahwa "perilaku pasar yang kacau tetap dapat diprediksikan, pasar bergerak dalam formasi sebuah gelombang yang terjadi secara berulang. Hal ini disebabkan karena setiap trader hamper selalu merespon dengan cara yang sama terhadap kejadian yang sama".

Hasil penelitian ini sejalan
dengan hasil penelitian yang dilakukan oleh Murwaningsari, pada tahun 2008 melakukan penelitian tentang prediksi IHSG, dengan menggunakan metode ARIMA dan GARCH, yang menunjukkan bahwa metode ARIMA memberikan hasil selisih nilai terkecil antara aktual dengan prediksi sebesar 47,34 (ARIMA) dan 258,48 (GARCH) dan sekaligus menegaskan bahwasanya hasil penelitian ini tidak sejalan dengan hasil penelitian yang dilakukan oleh Penelitian Jhon dan Yulia tahun 2008 tentang Perbandingan Kinerja ARIMA dan ARCH/GARCH Model Time Series Harga Harian Ekuitas untuk Perusahaan Besar yang membandingkan kinerja luar sampel ramalan-ramalan dari ARIMA dengan ARCH/GARCH dan menunjukkan perakiraan ARCH/GARCH model mengungguli model ARIMA. 


\section{PENUTUP}

Dari hasil penelitian dan pengolahan data, penelitian ini mengambil kesimpulan sebagai berikut:

1. Peramalan dengan menggunakan metode ARIMA menghasilkan persentase kesalahan absolut rata-rata sebesar 3,63\%. Hasil ini diperoleh dengan cara membandingkan selisih harga saham yang diramalkan dengan harga saham aktual kemudian dibandingkan dengan harga saham aktual.

2. Peramalan dengan menggunakan metode GARCH

menghasilkan persentase kesalahan absolut rata-rata sebesar $20,03 \%$. Hasil ini diperoleh dengan cara membandingkan selisih harga saham yang diramalkan dengan harga saham aktual kemudian dibandingkan dengan harga saham aktual.

3. Dari hasil peramalan dengan metode ARIMA dan GARCH, dapat disimpulkan bahwa metode ARIMA lebih akurat daripada metode GARCH karena metode ARIMA memiliki persentase kesalahan absolut rata-rata lebih kecil dibandingkan dengan persentase kesalahan absolut ratarata yang dimiliki GARCH $(3,63 \%$ $<$ 20,03\%). Semakin kecil persentase kesalahan absolut ratarata yang dihasilkan dari sebuah metode peramalan, maka metode peramalan tersebut akan dikatakan semakin akurat.

\section{DAFTAR PUSTAKA}

Aritonang, L. 2002. Peramalan Bisnis. Jakarta: Ghalia Indonesia.
Bodie, Z, A. Kane, dan A.J. Marcus. 2006. Investments. Buku 2. Edisi 6. Jakarta : Salemba Empat.

Firdaus, Muhammad. 2006. Analisis Deret Waktu Satu Ragam, ARIMA, SARIMA, ARCHGARCH. Bogor: IPB Press.

Halim, Abdul. 2005. Analisis Investasi. Jakarta : Salemba Empat.

Hirschey, Mark and Jhon Nofsinger. 2008. Investment and Behavior. Nw Delhi : The Me Graw Hill Componies.

Husnan, Suad. 2009. Teori Portofolio dan Analisis Sekuritas. Edisi Keempat. Yogyakarta: UPP STIM YKPN.

Jogiyanto, HM. 2010. Teori Portofolio dan Analisis Investasi. Edisi Ketujuh. Yogyakarta : BPFE.

Liummah, Khoiru dan Agus Suharsono. Analisis Volatilitas Saham Perusahaan Go Public dengan Metode ARCHGARCH. Jurnal Sains dan Seni ITS Vol. 1 No.1 September 2012. ISSN:2301-928X.

Marvillia, Bunga Lety. 2012. Pemodelan dan Peramalan Penutupan Hrga Saham PT. Telkom dengan Metode ARCHGARCH. Jurnal. Program Studi Matematika Fakultas Ilmu Pengetahuan Alam Universitas Negeri Semarang. 
JURNAL PLANS

Penelitian Ilmu Manajemen \& Bisnis

ISSN: 1978-7057

Muis, Saludin. 2008. Meramal Pergerakan Harga Saham Menggunakan Pendekatan Model ARIMA, Indeks Tunggal \& Markowits. Yogyakarta : Graha Ilmu.

Murwaningsari, Etty. 2008. Pengaruh Volume Perdagangan Saham, Deposito dan Kurs terhadap IHSG beserta Prediksi IHSG (Model GARCH dan ARIMA). Jurnal. Ekonomi Pembangunan Indonesia, Vol.23 No.2 hal 178-195.

Nachrowi dan Usman. 2007. Prediksi IHSG dengan model GARCH dan ARIMA. Jurnal. Ekonomi Pembangunan Indonesia, Vol VIII No.2 Januari.

Raharjo, Budi. 2009. Jeli Investasi Saham ala Warren Buffet Strategi Meraup Untung di Masa Krisis. Yogyakarta : Andi.

Rutato, Sabar. 2007. Pengantar Metodologi Penelitian. FKIP: Universitas Muria Kudus

Sadeq, Ahmad. 2008. Analisis Prediksi Indeks Harga Saham Gabungan dengan Metode ARIMA (Studi pada IHSG di Bursa Efek Jakarta). Tesis. Program Studi Magister Manajemen Program Pasca Sarjana Universitas Diponegoro.

Sparks, Jhon J. dan Yulia V. Yurova. 2008. Perbandingan Kinerja ARIMA dan ARCH/GARCH Model Time Series Harga
Harian Ekuitas untuk Perusahaan Besar. Journal of Forecasting, Departemen Ilmu Informasi dan Keputusan University of Illinois at Chicago University of Illinois di Chicago, Vol 19 No 1 hal 563-573.

Sugiyono. 2009. Manajemen Keuangan untuk Praktisi Keuangan. Jakarta: Grasindo.

Sugiyono. 2011. Metode Penelitian Kuantitatif , Kualitatif, dan $R \& D$. Bandung: AFABETA, cv.

Syamsir, Hendra. 2004. Solusi Investasi di Bursa Saham Indonesia. Jakarta: Salemba Empat

Tandelilin, Eduardus. 2001. Analisis Investasi dan Manajemen Portofolio. Edisi Pertama. Bandung: Alpha Betha, cv.

Tandelilin, Eduardus. 2010. Portofolio dan Investasi. Yogyakarta: Kanisius.

Taswan dan Euis Soliha. 2002. Prespektif Analisis Pelaku Investasi dan Spekulasi di Pasar Modal. Jurnal Fokus Ekonomi, Vol.1 No. Agustus hal 157-166.

Yani, Achmad. 2004. Analisis Teknikal Harga Saham dengan Metode ARIMA (Studi pada IHSG di Bursa Efek Jakarta). Tesis. Program Studi Magister Manajemen Program Pasca Sarjana Universitas Diponegoro. 